\title{
A STUDY OF ASSOCIATION BETWEEN ECONOMIC VALUE ADDED AND NET OPERATING PROFIT AFTER TAX: A CASE STUDY OF DIVIS LABORATORIES AND LUPIN LIMITED
}

\author{
Dr. Martina M. Noronha ${ }^{1}$, Ms. Deepa S. Pamnani ${ }^{2}$ \\ 1. Principal, Sir K.P. College of Commerce, Surat, Gujarat, India \\ 2. Asst. Professor, S.D.J International College, Surat, Gujarat,India
}

Article DOI: https://doi.org/10.36713/epra7252

DOI No: 10.36713/epra7252

\begin{abstract}
The purpose of this paper is to study relationship between Economic Value added and Net Operating Profit After Taxes Divis Laboratories and Lupin Limited. The period of study is 10 years ranging from 2009-10 to 2018-2019. Association is found between Economic Value Added and Net Operating Profit after Taxes for the given series and data is analysed by regression. ANOVA test is used to perform hypothesis testing. The study concludes that there is a positive relationship between EVA and Net Operating Profit After Taxes.

KEY WORDS: Economic Value Added, Net Operating Profit after Tax
\end{abstract}

\section{INTRODUCTION}

Economic Value added is the excess left after making a proper charge for the capital invested in the business. The concept of Economic Value Added is originally proposed by the consulting firm Stern Stewart \& Co. This concept accounts for the economic cost i.e. capital cost, which is not accounted in the traditional accounting measures.

Economic Value Added is calculated by the following formula:

$\mathrm{EVA}=$ NOPAT $-($ WACC $*$ C. E. $)$

Economic Value Added (EVA) focuses on the excess left after deducting the cost of capital from the profit. Whereas, Net Operating Profit After Tax (NOPAT) is an constituent for calculating EVA, which is derived from accounting profit. Here, an attempt has been made to investigate that does an increase or decrease in NOPAT leads to increase or decrease in the EVA.

\section{LITERATURE REVIEW}

1. Ahmed(2015) by examining the data of 5 Islamic banks listed on DSE for 5 years-With the help of regression and correlation study was concluded that Market value of share is more explained by EVA than traditional measures of profitability.

2. Nakhaei and Hamid(2013) studied the relationship between EVA and accounting variables (OP \& NP)with Market Value in Tehran Stock Exchange. Sample used is 87 companies listed in Tehran Stock Exchange for 5 years using correlation \& regression. They concluded that accounting variables have more relations with market value in comparison to EVA, but EVA has significant relationship with market value.

3. Shourvarzi and Sadeddin (2011) investigated the predictive ability of the components of EVA in predicting next periods operating profit in 119 companies for 6 years. 
Components of EVA are Return on assets, Cost of capital, Capital employed \& NOPAT by using simple linear regression and it is concluded that NOPAT has strong correlation with predicting next periods operating profit $\&$ cost of capital is very crucial in determining the same.

4. Biddle, Bowen and Wallace (1997) tested the assertions that EVA is more highly associated with stock returns than actual earnings. By using regression analysis they concluded that EVA does not dominate earnings in relative information content and suggest rather that the earnings generally outperform.

5. Grant (2006) estimated basic economic profit for healthcare providers and concluded that EVA can be adopted by making some adjustments to account profit like Medical training expenditure, community wellness. He also concluded that EVA adoption does not mean that accounting measures are not relevant.

Generally the research is undertaken as a comparison between value based measures and traditional accounting measures in determining the market price of the share. In this paper an attempt has been made to understand the relationship between NOPAT, being an accounting measure, and Economic Value Added, which being an value based measure.

\section{Objective of the study}

To Study the relationship between Economic Value Added and Net operating profit after tax of Divis Laboratories and Lupin Limited.

\section{Hypothesis}

H0: There is no significant relationship between

EVA and NOPAT

$\mathrm{H} 1$ : There is a significant relationship between EVA and NOPAT

\section{Database}

The data is collected from the website of BSE and respective companies website.

\section{Sample Selection}

Divis Laboratories and Lupin Limited have been selected from companies listed on BSE. Random sampling technique has been used for the said purpose.

\section{Period of the study}

The period of the study is 10 years i.e from Financial Year 2009-10 to 2018-19.

\section{DISCUSSION}

EVA is a dependent variable and NOPAT is an independent variable. All the Statistical analysis is done using MiniTab17 and Microsoft office Excel software.

The Statistical procedures followed are as follows:-

- Data Visualization

- Descriptive Statistics.

- Regression Analysis.

- ANOVA

\section{Relationship between EVA and NOPAT}

\section{Divis Laboratories}

Table Showing EVA and NOPAT

\begin{tabular}{|c|c|c|}
\hline Year & EVA & NOPAT \\
\hline 10-Mar & 236.829 & 366.5643 \\
\hline 11-Mar & 370.4852 & 459.9322 \\
\hline 12-Mar & 435.4428 & 549.6109 \\
\hline 13-Mar & 378.0338 & 633.3481 \\
\hline 14-Mar & 472.7617 & 797.3082 \\
\hline 15-Mar & 597.6359 & 924.3711 \\
\hline 16-Mar & 1120.354 & 1138.585 \\
\hline 17-Mar & 625.7545 & 1094.689 \\
\hline 18-Mar & 662.8924 & 891.1849 \\
\hline 19-Mar & 1162.135 & 1350.551 \\
\hline
\end{tabular}

Source: Computed 
EVA trend of Divis Laboratories over 10 Years

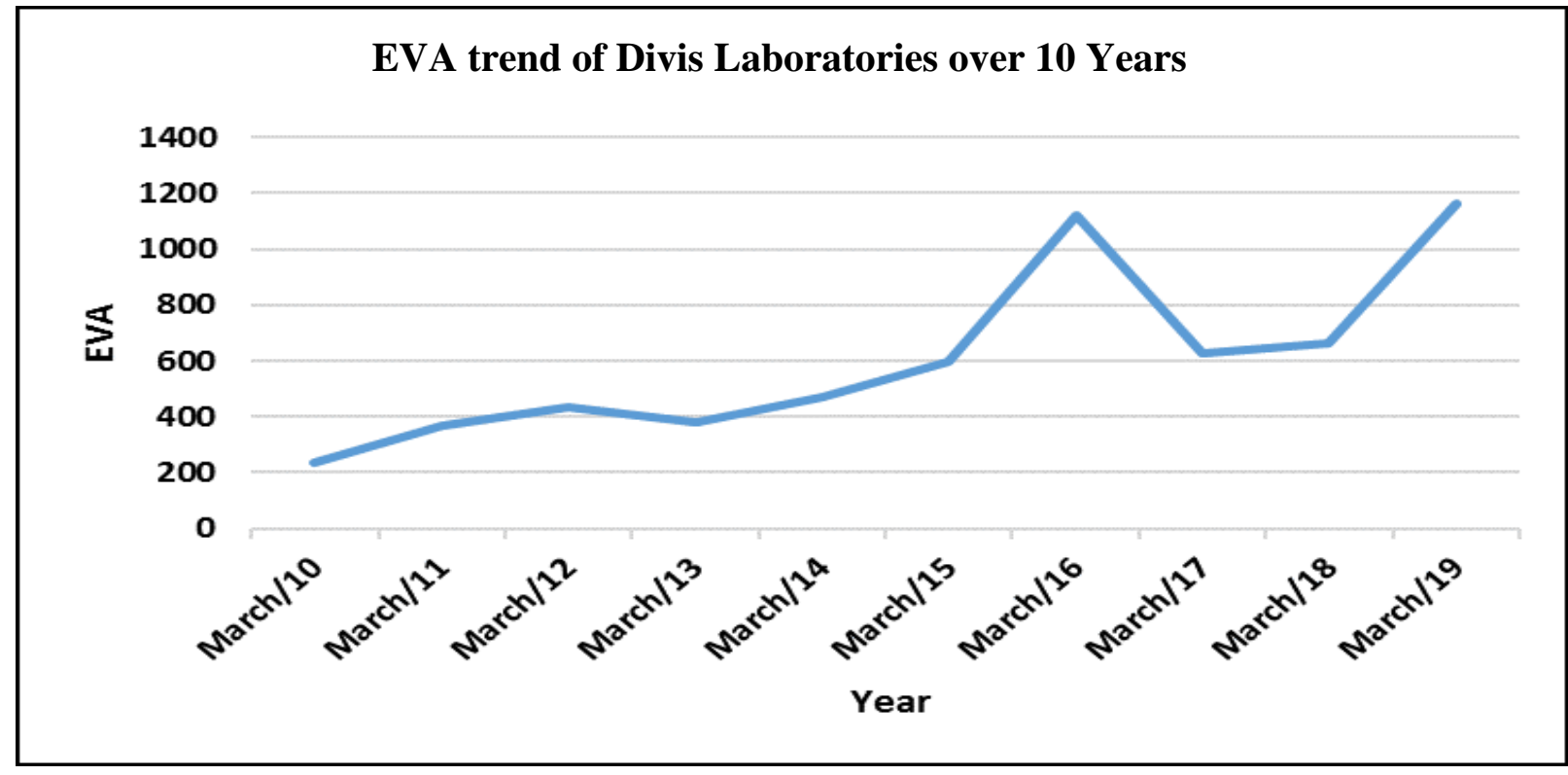

The above graph is the 10 years trend chart of EVA of Divis's Laboratories from March-10 to March-19.The graph shows the increasing trend from March-10 to March-16 and decreases in March-17 March-18 and then again increases. The data has minimum value Rs. 236.829Crores (in March-10) and maximum value Rs. 1162.135Crores (in March-19). The average EVA of Divis Laboratories over 10 year is 606.2324 with standard deviation 310.5743 .

\section{NOPAT trend of Divis Laboratories over 10 years}

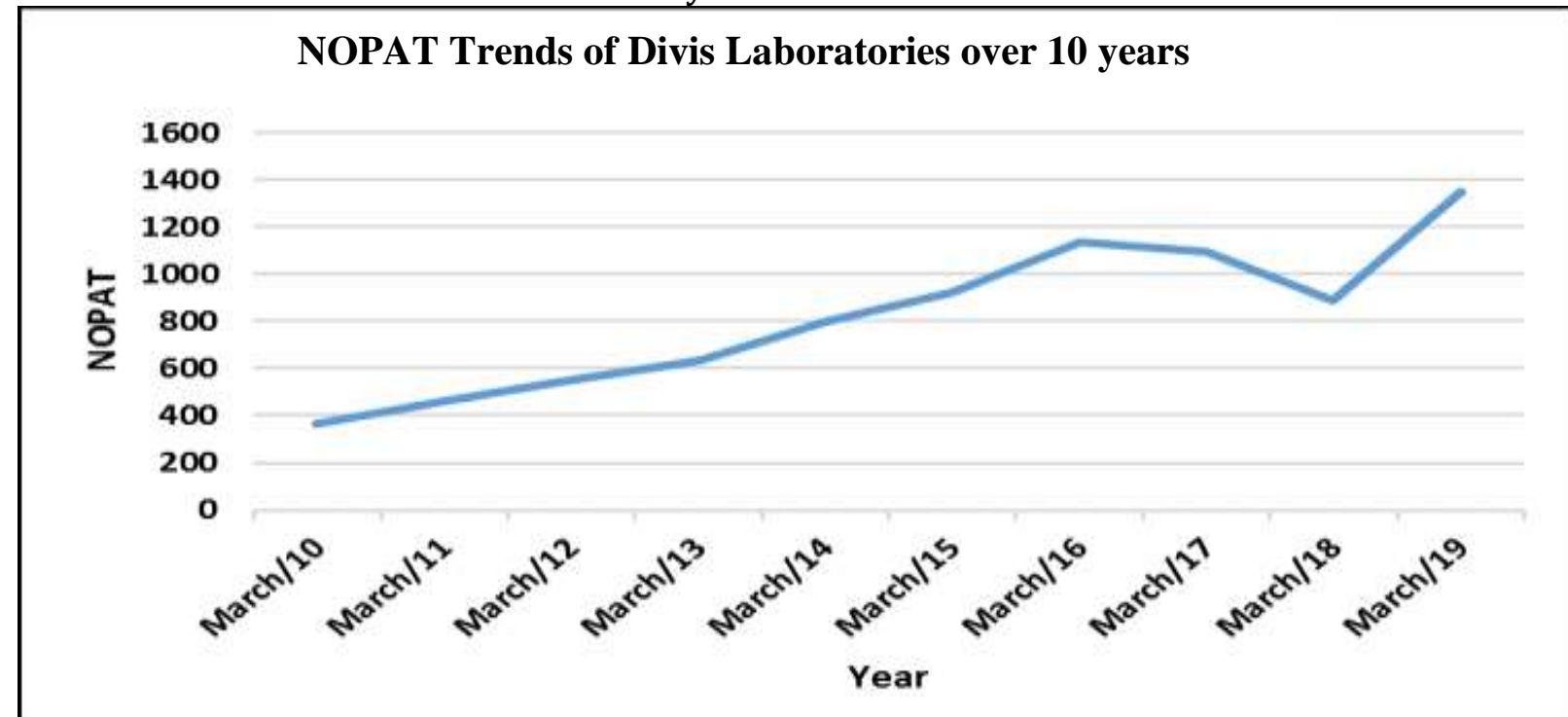

The above graph is the 10 years trend chart of NOPAT of Divis's Laboratories from March-10 to March-19.The graph shows the increasing trend from March-10 to March-17 and decreases in March-18. The data has minimum value Rs. 366.546 Crores (in March10) and maximum value Rs.1350.551 Crores (in
March-19). The average NOPAT of Divis Laboratories over 10 year is 820.6144 with standard deviation 319.3932 .

Ho: There is no relationship between NOPAT and EVA H1: There is relationship between NOPAT and EVA 
Chart showing relationship between NOPAT and EVA

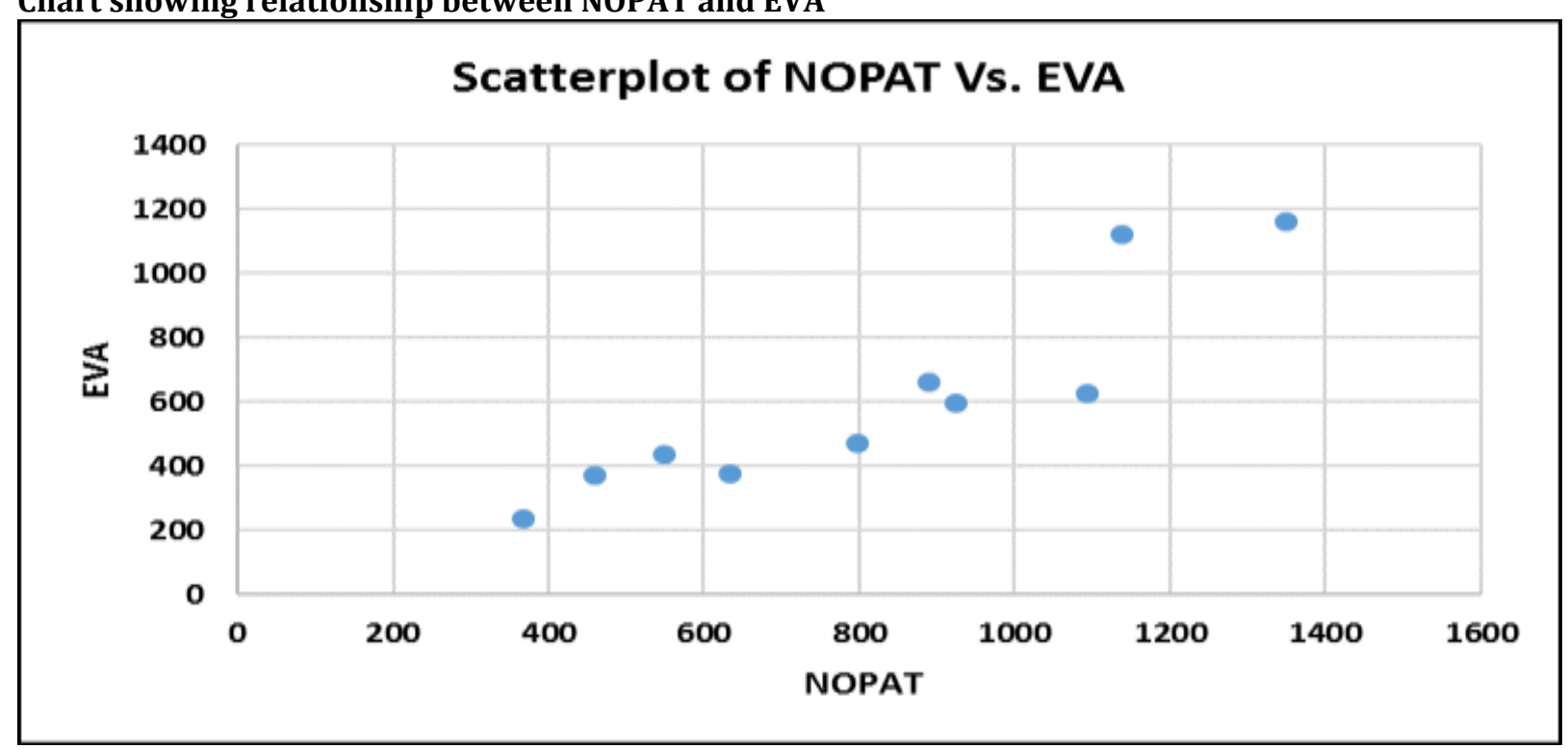

Observation

From the above graph it can be observed that with increase in NOPAT, EVA also increases.

\begin{tabular}{lr}
\hline \multicolumn{2}{c}{ Regression Statistics } \\
\hline Multiple R & 0.9089 \\
R Square & 0.8261 \\
Adjusted R Square & 0.8043 \\
Standard Error & 137.3827 \\
Observations & 10 \\
\hline
\end{tabular}

ANOVA

\begin{tabular}{lccccc}
\hline & Df & SS & MS & $\boldsymbol{F}$ & Significance $\boldsymbol{F}$ \\
\hline Regression & 1 & 717115 & 717115 & 37.9949 & 0.0003 \\
Residual & 8 & 150992 & 18874 & & \\
Total & 9 & 868107 & & & \\
\hline
\end{tabular}

Since the pvalue of the ANOVA is $0.0003<0.05$. The data provides enough evidence to reject Ho at $5 \%$ level of significance.

Hence we conclude that there is relationship between EVA and NOPAT.
The fitted regresssion equation is $\mathrm{EVA}=-119.016+$ $0.884 *$ NOPAT.

Here R-square is 0.8261 which means that $83 \%$ of the variation in EVA can be explanied by the fitted model.

\begin{tabular}{lcccccccc}
\hline & Coefficients & $\begin{array}{c}\text { Standard } \\
\text { Error }\end{array}$ & t Stat & P-value & $\begin{array}{c}\text { Lower } \\
\mathbf{9 5 \%}\end{array}$ & $\begin{array}{c}\text { Upper } \\
\mathbf{9 5 \%}\end{array}$ & $\begin{array}{c}\text { Lower } \\
\mathbf{9 5 . 0 \%}\end{array}$ & $\begin{array}{c}\text { Upper } \\
\mathbf{9 5 . 0 \%}\end{array}$ \\
\hline Intercept & -119.016 & 125.423 & -0.949 & 0.37 & -408.242 & 170.211 & -408.242 & 170.211 \\
NOPAT & 0.884 & 0.143 & 6.164 & 0 & 0.553 & 1.214 & 0.553 & 1.214 \\
\hline
\end{tabular}


Here the p-value of the parameter of NOPAT is 0.0000 $<0.05$ which concludes that the paramter is significant.
The value 0.884 in the fitted regression model indicates the expected change in EVA per unit change in NOPAT.

\section{Lupin Limited}

Table showing EVA and Sales of Lupin Limited (Rs. In Crores)
\begin{tabular}{|c|c|c|}
\hline Year & EVA & NOPAT \\
\hline 10-Mar & 463.9801 & 693.2292 \\
\hline 11-Mar & 767.5522 & 929.4816 \\
\hline 12-Mar & 657.8166 & 943.44 \\
\hline 13-Mar & 832.8015 & 1385.467 \\
\hline 14-Mar & 1478.675 & 2162.088 \\
\hline 15-Mar & 1793.949 & 2532.533 \\
\hline 16-Mar & 2776.575 & 2950.38 \\
\hline 17-Mar & 2161.647 & 3368.745 \\
\hline 18-Mar & 813.6551 & 1564.395 \\
\hline 19-Mar & 1231.538 & 1865.635 \\
\hline
\end{tabular}

EVA trend of Lupin Limited over 10 Years

\section{EVA Trend of Lupin Limited over 10 years}

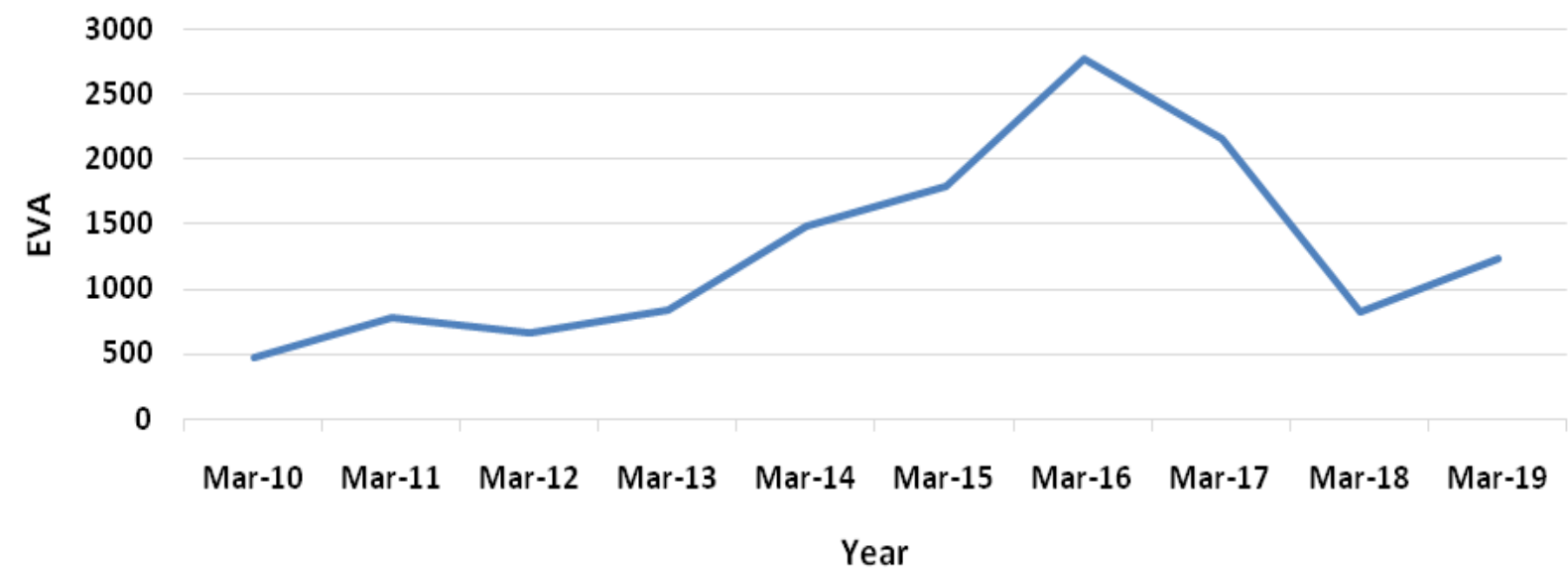

The above graph is the 10 years trend chart of EVA of Lupin Limited from March-10 to March19.The graph shows the increasing trend from March10 to March-16 and decreases from March-16 to March-18 then again increases. The data has minimum value Rs.463.9801Crores (in March-10) and maximum value Rs. 2776.575 Crores (in March-16). The average value of EVA over 10 year is Rs.1297.819 crores with standard deviation 749.288 . 


\section{NOPAT trend of Lupin Limited over 10 Years}

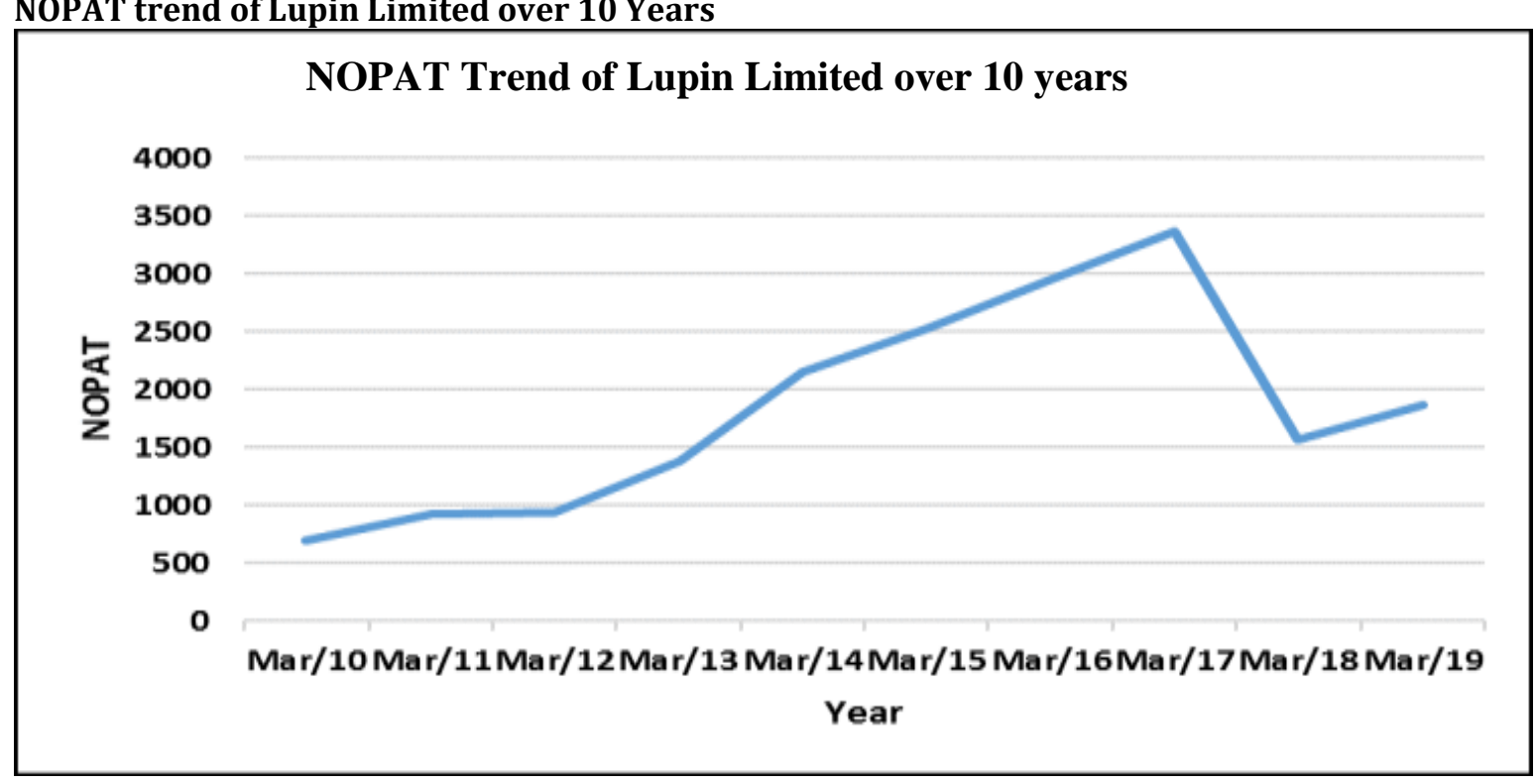

The above graph is the 10 years trend chart of NOPAT of Lupin Limited from March-10 to March19.The graph shows the increasing trend from March10 to March-17 and decreases in March-17. The data has minimum value Rs. 943.44 Crores (in March-12) and maximum value Rs.3368.745 (in March-17). The average NOPAT of Lupin Limited over 10 year is 1839.539 with standard deviation 905.815 .

Ho: There is no relationship between EVA and NOPAT.

H1: There is relationship between EVA and NOPAT.

\section{SUMMARY OUTPUT}

\begin{tabular}{lr}
\hline \multicolumn{2}{c}{ Regression Statistics } \\
\hline Multiple R & 0.9365 \\
R Square & 0.877 \\
Adjusted R Square & 0.8616 \\
Standard Error & 278.7677 \\
Observations & 10 \\
\hline
\end{tabular}

\begin{tabular}{lccccc}
\hline & $\boldsymbol{d} \boldsymbol{f}$ & $\boldsymbol{S S}$ & $\boldsymbol{M S}$ & $\boldsymbol{F}$ & Significance $\boldsymbol{F}$ \\
\hline Regression & 1 & 4431201 & 4431201 & 57.02124 & $6.60 \mathrm{E}-05$ \\
Residual & 8 & 621691.4 & 77711.42 & & \\
Total & 9 & 5052893 & & & \\
\hline
\end{tabular}

Since the pvalue of the ANOVA is less than 0.05 . The data provides enough evidence to reject $\mathrm{Ho}$ at $5 \%$ level of significance.

Hence we conclude that there is relationship between EVA and NOPAT.
The fitted regresssion equation is $\mathrm{EVA}=-127.1622+$ $0.7746 *$ NOPAT.

Here R-square is 0.8770 which means that $87 \%$ of the variation in EVA can be explanied by the fitted model. 


\begin{tabular}{lcccccccc}
\hline & Coefficients & $\begin{array}{c}\text { Standard } \\
\text { Error }\end{array}$ & t Stat & P-value & Lower 95\% & $\begin{array}{c}\text { Upper } \\
\mathbf{9 5 \%}\end{array}$ & $\begin{array}{c}\text { Lower } \\
\mathbf{9 5 . 0 \%}\end{array}$ & $\begin{array}{c}\text { Upper } \\
\mathbf{9 5 . 0 \%}\end{array}$ \\
\hline Intercept & -127.1622 & 208.2833 & -0.6105 & 0.5585 & -607.4642 & 353.14 & -607.46 & 353.14 \\
NOPAT & 0.7746 & 0.1026 & 7.5512 & 0.0001 & 0.5381 & 1.0112 & 0.5381 & 1.0112 \\
\hline
\end{tabular}

Here the p-value of the parameter of NOPAT is 0.0001 $<0.05$ which concludes that the paramter is significant. The value 0.7746 in the fitted regression model indicates the expected change in EVA per unit change in NOPAT.

\section{FINDINGS}

From the above analysis, it can be found out that both Divis Laboratories and Lupin Limited show a positive relationship between EVA and NOPAT. There is a scope for further study by increasing the size of sample with more companies and other accounting variables like Sales, Return on Assets and other traditional accounting measures can be used for studying the relationship.

\section{REFERENCES}

1. Ahmed, H. (2015). Impact of firms earnings and economic value added on the market share value: An empirical study on the Islamic banks in Bangladesh. Global Journal of Management and Business Research.

2. Biddle, G. C., Bowen, R. M., \& Wallace, J. S. (1997). Does EVA® beat earnings? Evidence on associations with stock returns and firm values. Journal of accounting and economics, 24(3), 301-336.

3. Grant (2006)., A Primer on EVA for Healthcare Providers . Financial Services Forum Publications. Paper 18.

4. Nakhaei, H., Hamid, N. I. N. B., Anuar, M. B. A., \& Nakhaei, K. (2012). Performance evaluation using accounting variables (net profit and operational profit) and economic measures. International Journal of e-Education, e-Business, e-Management and e-Learning, 2(5), 443.

5. Phani, B., \& Bhattacharyya, A. K. (2000). Economic Value Added-A General Perspective. Volume 27, No.2, July-Dec 2000, 25-55

6. Shourvarzi, M. R., \& Sadeddin, S. (2011). Analysis of the predictive ability of the components of economic value added in predicting next periods operating profit: Evidence from Iran. African Journal of Business Management, 5(8), 3251-3258.

7. Stewart, B. G. (1994). "EVA: Fact or Fantasy". Journal of Applied Corporate Finance. Volume 16. Issue No. 2-3, 91-99.

Books

8. Chandra Prasanna (2011). "Financial Management: Theory and Practice" McGraw Hill. Eighth Edition ,801-811.

\section{Recommended websites}

1. Yahoo Finance: https://in.finance.yahoo.com/

2. BSE - Historical Indices: https://www.bseindia.com/Indices/IndexArchiveData.h tml

3. https://www.divislabs.com/

4. https://lupin.com/ 